\title{
EFFICIENCY OF THE APPLICATION OF ACTIVATING FLUXES IN SHIELDED ARC WELDING
}

\author{
Oleksandr M. Savytsky, Mychailo M. Savytsky, Darko Bajić
}

Original scientific paper

In this paper we will present our results related to the impact of activating fluxes in shielded arc welding with consumable or non-consumable electrode to the process productivity, intensity of the energy necessary for welding and the quality of welding joints. Thanks to the application of activating fluxes, during the use of non-consumable electrode, the penetration capability of electric arc is increased by 2 to 3 times, and during the use of consumable electrode 1,8 to 4 times, with simultaneous decrease of the intensity of the necessary welding energy by 2 to 5 times. At the same time, the productivity of a welding process and quality of welding joints increases. These positive effects of the welding process are conditioned by an increase in thermal coefficient of arc penetration and total heat coefficient of arc penetration

Keywords: activating fluxes; driving energy; efficiency; electric arc welding; penetration; thermal coefficient; total heat coefficient

Efikasnost primjene aktivirajućih topitelja pri elektrolučnom zavarivanju u zaštitnoj atmosferi

Izvorni znanstveni članak

U radu su prezentirani rezultati istraživanja utjecaja aktivirajućih topitelja pri elektrolučnom zavarivanju u zaštitnoj atmosferi topljivom i netopljivom elektrodom na proizvodnost procesa, intenzitet potrebne energije zavarivanja i kvalitetu zavarenih spojeva. Zahvaljujući primjeni aktivirajućih topitelja, pri zavarivanju netopljivom elektrodom povećava se penetraciona sposobnosti električnog luka $2 \div 3$ puta, a pri zavarivanju topljivom elektrodom $1,8 \div 4$ puta, uz istovremeno sniženje $2 \div 5$ puta intenziteta potrebne energije zavarivanja. Istovremeno, povećava se proizvodnost procesa zavarivanja i kvaliteta zavarenih spojeva. Ovi pozitivni efekti procesa zavarivanja su uvjetovani suštinskim povećanjem toplinskog koeficijenta penetracije električnog luka i ukupnog toplinskog koeficijenta penetracije električnog luka.

Ključne riječi: aktivirajući topitelji; pogonska energija; efikasnost; elektrolučno zavarivanje; penetracija; toplinski koeficijent; ukupni toplinski koeficijent

\section{Introduction}

Out of all materials, steel is the most frequently used for different applications. It should be expected that this metal, due to its properties, will remain the most useful and most frequently used material for product manufacturing. Although, for the several last decades, we have been intensively developing modern welding procedures, such as laser, electron beam and hybrid, their widespread use has yet to be seen. Thanks to its high productivity, mobility, simplicity and low equipment costs, electric arc welding, with both consumable and non-consumable electrode, has remained dominant [1,2].

One of the most widespread electric arc welding procedures is the one shielded by an inert gas. This procedure provides for high quality welding joints which can be completed in almost all environments with the possibility of welding automation. Additionally, from the standpoint of an expert, inert gas shielded welding is characterised as a process with the highest purity level when compared to other electric arc welding procedures [3]. One of the basic concepts related to the development of worldwide industrial production is the application of manufacturing processes with high level of environmental protection.

Inert gas shielded welding can be performed with either non-consumable (TIG) or consumable (MIG) electrode. TIG welding is characterised by its simplicity, but it yields high quality welding joints. Due to this, the procedure is widely used in atomic energetics, thermal energetics and aviation and high-tech industry.

MIG welding is characterised by high productivity and yields high quality welding joints which are almost of the same quality as the ones done with TIG welding process.

With regard to the above-mentioned, increasing efficiency, when it comes to inert gas shielded welding procedures is an on-going task. The efficiency of a welding procedure is assessed in accordance to general indicators, such as: productivity, energy necessary for the welding procedures and quality of welded joints. Process efficiency increases with increased productivity and welded joint quality, while at the same time we are trying to decrease energy consumption.

\section{Problem analysis}

It is known that electric arc has limited penetration capabilities. Due to this fact, for inert gas welding of $>3 \mathrm{~mm}$ steel, it is necessary to perform preventive preheating [2]. Experiments show that, due to electric arc low penetration capability, it is useful to apply preheating when it comes to welding using non-consumable electrode (TIG). While utilising consumable welding procedure (MIG), where electric arc penetration capability is significantly higher, preventive preheating is useful for materials thicker $>5 \mathrm{~mm}$.

Depending on the thickness of a material, necessary preparation of workpieces may be done on one or both sides which have "V" or "U" shaped groove. This preparation of workpieces demands for the groove to be filled by additional electrode material. In this case, welding productivity is defined by the quantity of deposited material, where productivity increases with an increase in intensity of welding current. In this method of increasing welding efficiency, the increase of one 
indicator (productivity) leads to the deterioration of the second indicator (energy intensity increase).

Additionally, increase in welding energy intensity invariably leads to the increased heat input to welding joints. This leads to steel overheating which causes coarsening of the grains of metal in the weld area (grain growth) $[1,2]$, cold cracking in the weld metal $[4,5]$, increases crystallisation time and increases the possibility for hot cracking to occur [6]. This negative trend is further made more difficult with an increase in content of carbon and some other alloy materials in welded steels.

Increase in intensity of welding energy, in order to increase conventional metal inert gas welding productivity has limited perspective. Interdependence between welding energy intensity and electric arc productivity is not conducive for any significant change of any indicator in a positive sense, without an immediate change of the second indicator in a negative sense.

Therefore, we can say that in order to increase the efficiency of shielded arc welding it is necessary to increase electric arc penetration capability. This would enable us to increase the thickness of steel which can be welded in a single pass, without prior preparation of workpieces. However, penetration depth with electric arc welding depends on several parameters, such as: welding current, electric arc voltage, welding speed and efficiency of heating of metal by electric arc. These parameters are the components of driving welding energy $\left(q_{\mathrm{i}} / V_{\mathrm{w}}\right)$ which defines the amount of heat transferred to the metal while welding $[7 \div 9]$ :

$\frac{q_{\mathrm{i}}}{V_{\mathrm{w}}}=I \cdot U \cdot \frac{\eta_{\mathrm{i}}}{V_{\mathrm{w}}}, \mathrm{J} / \mathrm{cm}$

where $q_{\mathrm{i}}(\mathrm{J} / \mathrm{s})$ is the arc thermal power, $V_{\mathrm{w}}(\mathrm{cm} / \mathrm{s})$ is welding speed, $I / \mathrm{A}$ is welding current, $U / V$ is arc voltage, $\eta_{\mathrm{i}}$ is effective coefficient of usefulness of electric arc.

Fig. 1 shows the dependence between penetration depth and welding energy while utilising consumable $1,2 \mathrm{~mm}$ electrode. It can be clearly seen that the increase in penetration depth invariably leads to the increase in driving energy and, at the same time, welding energy intensity. Same interdependence is valid for welding with non-consumable electrode.

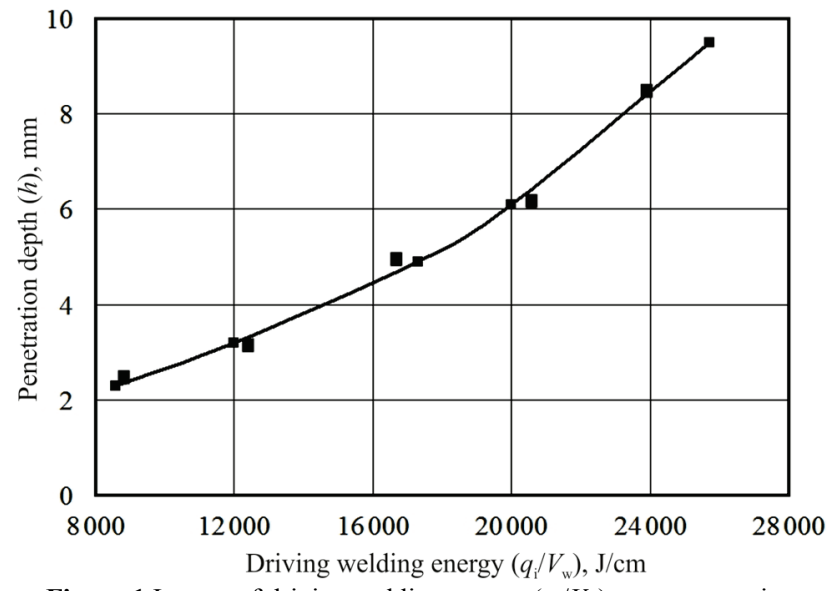

Figure 1 Impact of driving welding energy $\left(q_{\mathrm{i}} / V_{\mathrm{w}}\right)$ onto penetration depth $(h)$
While utilising consumable electrode, apart from driving energy, penetration depth is also influenced by the electrode diameter. The degree and character of such impact can be assessed in Fig. 2, which shows the dependence of current density and penetration depth and electrode diameter at the constant value of welding current $(I=300 \mathrm{~A})$ and driving energy $\left(q_{i} / V_{w}=16071\right.$ $\mathrm{J} / \mathrm{cm})$. It can be seen that reduced electrode diameter increases welding current density due to which root penetration depth increases.

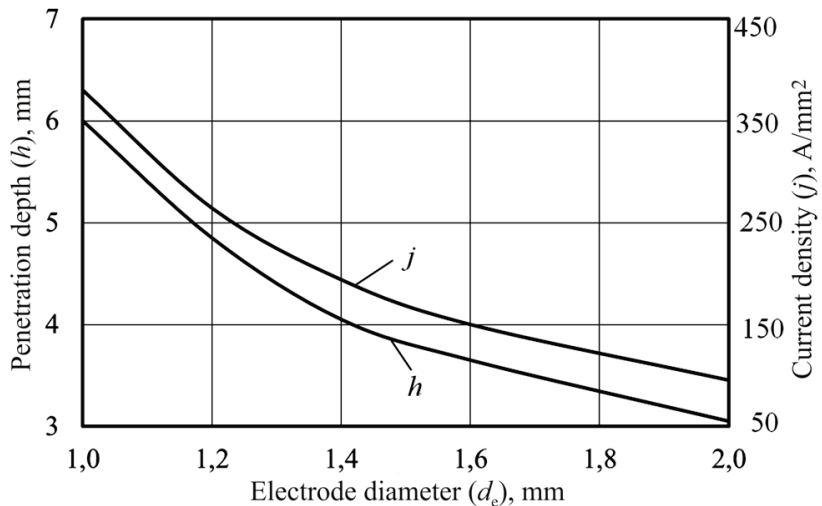

Figure 2 Impact of electrode diameter $\left(d_{\mathrm{e}}\right)$ onto current density $(j)$ and penetration depth $(h)$

This interdependence is also valid for nonconsumable electrode, because as we know, due to wear and tear of non-consumable electrode penetration depth decreases.

Thus, in order to increase electric arc penetration capability it is necessary to increase its current density, which is enabled by the application of activating fluxes. Their application in inert gas welding (ATIG and AMIG) increases penetration depth several times when compared to conventional TIG and MIG welding procedures $[3,10$, 11], without increasing welding current intensity.

At the same time, as it is mentioned in the text above, conventional TIG and MIG welding procedures differ in efficiency indicators. Due to that, it is necessary to determine the impact of activating fluxes onto the abovementioned efficiency indicators in ATIG and AMIG welding procedures.

\subsection{Paper aim}

The aim of this paper is to assess the efficiency of application of activating fluxes in shielded arc welding of steels of different thicknesses with non-consumable (ATIG) and consumable (AMIG) electrode.

In order to archive the desired result, it is necessary to perform the following tasks:

- assess the character and efficiency of the influence of activating fluxes onto driving energy while welding with non-consumable and consumable electrode,

- analyse the influence of activating fluxes onto the welding productivity and quality of welding joints and

- define thermal and total heat coefficient of electric arc penetration. 


\subsection{Base metal}

Testings were conducted using a base metal ferritepearlite stee 120 (GOST). Chemical composition of steel 20 is provided in Tab. 1

Table1 Chemical composition from the steel 20 (GOST), wt. \%

\begin{tabular}{|c|c|c|c|c|c|c|}
\hline $\mathrm{C}$ & $\mathrm{Mn}$ & $\mathrm{Si}$ & $\mathrm{Cr}$ & $\mathrm{Ni}$ & $\mathrm{S}$ & $\mathrm{P}$ \\
\hline 0,22 & 0,48 & 0,17 & 0,22 & 0,21 & 0,03 & 0,035 \\
\hline
\end{tabular}

ATIG welding is implemented in a single-run welding with root penetration, without joint preparation and without filler material.

AMIG welding is implemented in a single-run welding with root penetration, without joint preparation and with filler material Sv08G2S (GOST). Chemical composition and mechanical properties metal cored electrode of diameter $\varnothing 1,2 \mathrm{~mm}$ is provided in Tabs. 2 and 3.

Table 2 Chemical composition of the metal cored electrode Sv08G2S (GOST), wt. \%

\begin{tabular}{|c|c|c|c|c|c|c|}
\hline $\mathrm{C}$ & $\mathrm{Mn}$ & $\mathrm{Si}$ & $\mathrm{Cr}$ & $\mathrm{Ni}$ & $\mathrm{S}$ & $\mathrm{P}$ \\
\hline 0,22 & 0,48 & 0,17 & 0,22 & 0,21 & 0,03 & 0,035 \\
\hline
\end{tabular}

Table 3 Mechanical properties of the metal cored electrode

\begin{tabular}{|c|c|c|c|c|c|}
\hline Yield & Ultimate & & \multicolumn{3}{|c|}{ Impact toughness } \\
tensile & Elongation & \multicolumn{3}{|c|}{$K C U / \mathrm{J} / \mathrm{cm}^{2}$} \\
\cline { 5 - 7 } strength & $\begin{array}{c}\text { Strength } \\
R_{\mathrm{p} 0,2} / \mathrm{MPa}\end{array}$ & $A_{5} / \%$ & $+20{ }^{\circ} \mathrm{C}$ & $-40{ }^{\circ} \mathrm{C}$ & $-70^{\circ} \mathrm{C}$ \\
\hline 345 & $R_{\mathrm{m}} / \mathrm{MPa}$ & & 64 & 39 & 70 \\
\hline
\end{tabular}

Metal cored electrode Sv08G2S is used as a filler material for TIG i MIG welding the steel20.

\section{Experiments and analysis results}

Activating fluxes, depending on their purity level during ATIG procedure, increase steel penetration depth 2 to 3 times. For the case when we use consumable electrode, application of activating fluxes (AMIG procedure) enables the increase in penetration depth from 1,8 to 4 times. Thus, while welding the steel of the same thickness, ATIG and AMIG procedures, in the similar manner and to the similar degree, decrease the necessary driving energy when compared to the conventional TIG and MIG procedures. At the same time, they cannot have any negative impact on the production process and quality of welding joints.

Fig. 3 shows the results of the testing related to the character and degree of impact of activating fluxes on driving energy in electric arc welding of $3,5 \mathrm{~mm}$ and $6 \mathrm{~mm}$ metal workpiece. These results indicate that for a complete penetration of $3,5 \mathrm{~mm}$ steel, when utilising a conventional TIG procedure, the necessary driving energy is $5890 \mathrm{~J} / \mathrm{cm}$. Use of activating fluxes (ATIG procedure) enables the driving energy which is necessary to penetrate the steel of the same size to be reduced to $2162 \mathrm{~J} / \mathrm{cm}$, which is 2,72 times less than in the conventional procedure.

Same relation may be applied to the welding of $6 \mathrm{~mm}$ thick steel (Fig. 3). During a single pass welding with a complete penetration of the steel of this thickness, with TIG welding procedure the necessary driving energy is
$11520 \mathrm{~J} / \mathrm{cm}$. Use of activating fluxes (ATIG) enables for driving energy to be reduced to $6057 \mathrm{~J} / \mathrm{cm}$, which is 1,9 times less than without electric arc activation.

Comparison of efficiency of application of activating fluxes with a single pass complete penetration of $3,5 \mathrm{~mm}$ and $6 \mathrm{~mm}$ thick steel shows that with an increase in welded steel thickness, the efficiency of impact of electric arc activation onto welding driving energy gradually decreases, Fig. 3.

Influence of activating fluxes onto the productivity of arc welding with non-consumable electrode shielded in argon may be assessed in the following manner as well.

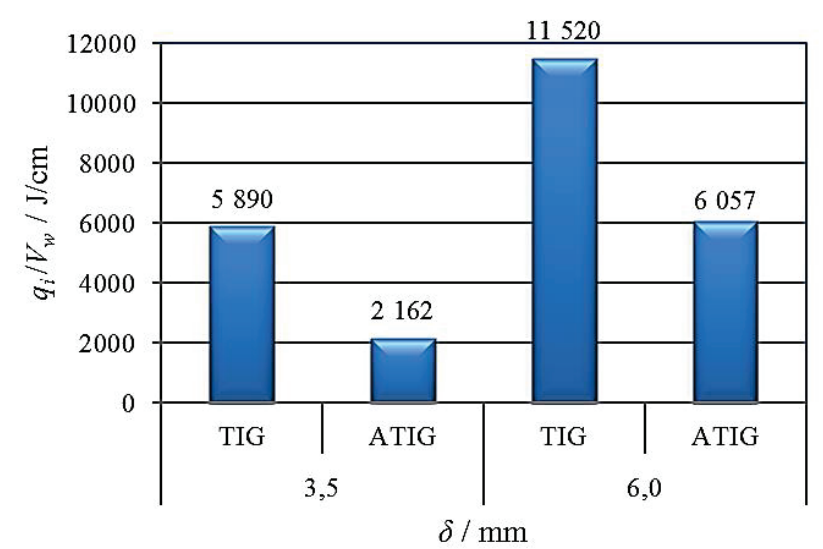

Figure 3 Influence of the activating fluxes on drive energy in arc welding with non-consumable electrode shielded in argon

Groove preparation is necessary for TIG welding procedure for $3,5 \mathrm{~mm}$ and $6 \mathrm{~mm}$ steel. In that case, in order to have a $3,5 \mathrm{~mm}$ weld seam, we need 2 to 3 passes (depending on the groove shape): 1 root pass, 1 or 2 fill passes. With $6 \mathrm{~mm}$ steel, depending on the groove shape, we need 4 to 6 passes: 1 root pass, 3 to 5 fill passes.

Use of activating fluxes enabled us to get weld seams in a single pass, which speaks volumes about ATIG procedure productivity. What is more, the quality of welding joint is not reduced.

Fig. 4 shows weld seams microstructure of ferritepearlite steel, where the seams were obtained through TIG and ATIG welding procedure. From their comparison, we can conclude that TIG welding procedure creates larger crystal grains with clearly defined outline. ATIG welding enables for the grains to be much finer and with less clearly defined outline, which indicates that the process of weld seam crystallisation was faster. Positive changes in the structure of weld seams with ATIG procedure lead to their better mechanical properties (Tab. 4), which are, according to many indicators, better than weld seams made with TIG procedure [12].

However, as it is mentioned in the text above, increased thickness of a workpiece gradually decreases the efficiency of applied activating fluxes. According to all indicators, depending on the flux chemical composition, maximum efficiency of the process while using activating flux is achieved when we have $6 \div 8 \mathrm{~mm}$ thick steel. We have experimentally determined that activating fluxes in welding with non-consumable electrode, according to some indicators keep, although a slightly lower, high degree of efficiency up to the thickness of $10 \div 12 \mathrm{~mm}$. 


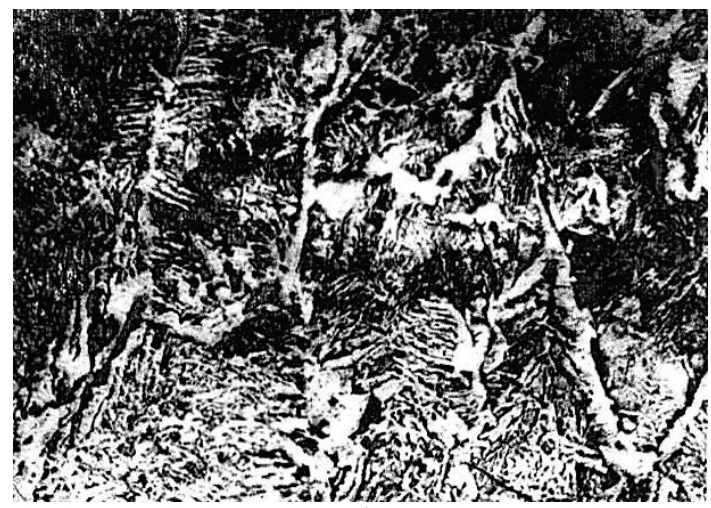

a)

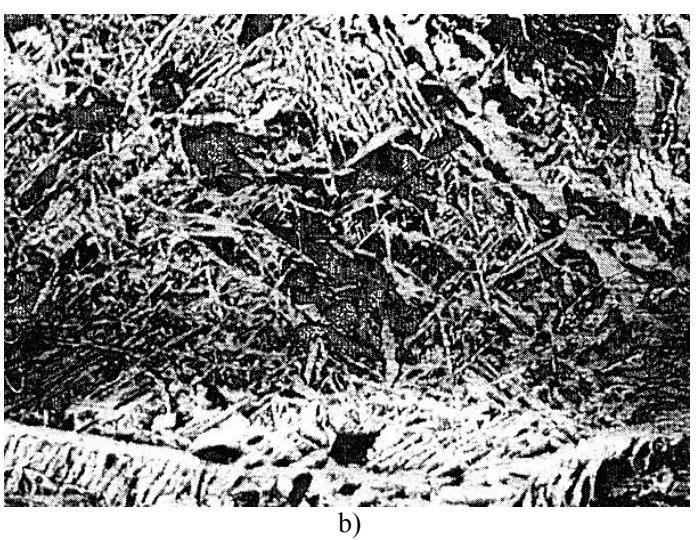

Figure 4 Microstructure of ferrite-pearlite steel weld joints, completed by: a) TIG welding procedure $(\times 150)$; b) ATIG welding procedure $(\times 150)$

Table 4 Mechanical properties of welding joints completed by arc welding with non-consumable electrode shielded in argon [12]

\begin{tabular}{|c|c|c|c|c|c|c|c|c|}
\hline \multirow[b]{2}{*}{$\begin{array}{l}\text { Type of steel- } \\
\text { GOST (class) }\end{array}$} & \multirow[b]{2}{*}{$\begin{array}{l}\text { Welding } \\
\text { procedure }\end{array}$} & \multicolumn{7}{|c|}{ Mechanical properties on $+20^{\circ} \mathrm{C}$} \\
\hline & & $\begin{array}{c}\text { Yield } \\
\text { strength } \\
R_{\mathrm{e}} / \mathrm{MPa} \\
\end{array}$ & $\begin{array}{c}\text { Tensile } \\
\text { strength } \\
R_{\mathrm{m}} / \mathrm{MPa} \\
\end{array}$ & $\begin{array}{c}\text { Elongation } \\
\delta / \%\end{array}$ & $\begin{array}{c}\text { Contraction } \\
\psi / \%\end{array}$ & $\begin{array}{c}\text { Impact } \\
\text { toughness } \\
K C U / \mathrm{J} / \mathrm{cm}^{2}\end{array}$ & $\begin{array}{c}\text { Impact } \\
\text { toughness } \\
K C V / \mathrm{J} / \mathrm{cm}^{2}\end{array}$ & $\underset{/ \circ}{\text { Bending angle }}$ \\
\hline \multirow{2}{*}{$\begin{array}{c}20 \\
\text { (ferrite-pearlite) }\end{array}$} & TIG & 340 & 470 & 18,5 & 67,0 & 105 & 64 & $\begin{array}{c}180^{\circ} \\
\text { (no cracks) }\end{array}$ \\
\hline & ATIG & 388 & 499 & 22,3 & 71,6 & 116 & 78 & $\begin{array}{c}180^{\circ} \\
\text { (no cracks) }\end{array}$ \\
\hline
\end{tabular}

Due to that, if the thickness of steel is greater than $8 \mathrm{~mm}$ it is prudent to use AMIG welding procedure. Depending on the chemical composition of activating fluxes, penetration depth is increased by 1,8 to 4 times. Tab. 5 shows these experimental results, which confirm that a single pass welding with a complete penetration of $10 \mathrm{~mm}$ thick steel with a consumable electrode shielded by inert gases needs the energy of $24964 \mathrm{~J} / \mathrm{cm}$. Application of an activating flux enables for this energy to be reduced by several times without any negative impact on welding productivity.

Table 5 The impact of activating fluxes onto driving energy for shielded welding with consumable electrode

\begin{tabular}{|c|c|c|c|c|}
\hline $\begin{array}{c}\text { Welding } \\
\text { procedure }\end{array}$ & $\begin{array}{c}\text { Penetration } \\
\text { arc }\end{array}$ & $\begin{array}{c}\text { Material } \\
\text { thickness } \\
\delta / \mathrm{mm}\end{array}$ & $\begin{array}{c}\text { Welding } \\
\text { speed } \\
V_{w} / \mathrm{m} / \mathrm{h}\end{array}$ & $\begin{array}{c}\text { Driving } \\
\text { energy } \\
q_{i} / V_{w} / \mathrm{J} / \mathrm{cm}\end{array}$ \\
\hline MIG & 1 & 10 & 25 & 24964 \\
\hline AMIG & 1,8 & 10 & 40 & 9189 \\
\hline AMIG & $2,0 \div 2,5$ & 10 & 30 & 8103 \\
\hline AMIG & $3 \div 4$ & 10 & 36 & 4400 \\
\hline
\end{tabular}

Application of activating fluxes (AMIG) increases root penetration depth by 1,8 times, which creates conditions to get a quality single pass welding joint (steel thickness of $10 \mathrm{~mm}$ ) with driving energy of $9189 \mathrm{~J} / \mathrm{cm}$. This energy value is 2,72 times less than it is necessary with a conventional MIG welding procedure.

Further increase of penetration by 2 to 2,5 times at the expense of activating flux, enables the additional decrease of driving energy (threefold) which is necessary for a quality single pass welding joint (steel thickness of $10 \mathrm{~mm}$ ) with driving energy of up to $8103 \mathrm{~J} / \mathrm{cm}$.

Application of activating flux, increases penetration depth by 4 times, enables the decrease of the necessary driving energy for a quality single pass welding joint (steel thickness of $10 \mathrm{~mm}$ ) with driving energy of up to $4400 \mathrm{~J} / \mathrm{cm}$. It is 5,67 times less than with a conventional MIG welding procedure.

Data from Tab. 4 confirm that the application of activating fluxes, while utilising consumable electrode shielded by inert gases, does not decrease just the intensity of welding energy, but increases its productivity. Application of activating fluxes can be used to get a quality single pass welding joint (steel thickness of $10 \mathrm{~mm}$ ) with the speed of $30 \div 40 \mathrm{~m} / \mathrm{h}$. With the conventional procedure, in order to have the same welding joint, the speed is $25 \mathrm{~m} / \mathrm{h}$.

If, during the conventional MIG welding procedure (steel thickness of $10 \mathrm{~mm}$ ) we have preventive workpiece preparation, depending on its shape, we need $3 \div 4$ passes: 1 root pass, 2 to 3 fill passes. By using activating fluxes, we can weld the above-mentioned steel thickness with a single pass without preventive workpiece preparation, which influences the increase in welding process productivity.

Metallographic examination of the mentioned welding joints confirms that with AMIG welding, in welding joints, we have the creation of micro-grain structure which is composed of pearlite, ferrite and minute traces of bainite (Fig. 5), characterised by the increased values of toughness and plasticity. The results of the mechanical examinations of impact toughness (Fig. 6) show that welding steel joints with carbon content of $0,22 \%$, have high parameters of impact toughness within the temperature range from $+20^{\circ} \mathrm{C}$ to $-50{ }^{\circ} \mathrm{C}$. At the same time, impact toughness of the base metal within this temperature range is decreased 2,4 times.

So, the examination results show that the use of activating fluxes is beneficial in order to reduce the intensity of driving energy and, at the same time, increase process productivity and improve welding joints quality. Maximum efficiency while using activating fluxes and non-consumable electrode (ATIG) is achieved with the steel thickness of $6 \div 8 \mathrm{~mm}$. Welding of the steel with its thickness of $8 \div 10 \mathrm{~mm}$, is more efficient with the use of consumable electrodes with activating fluxes (AMIG). 


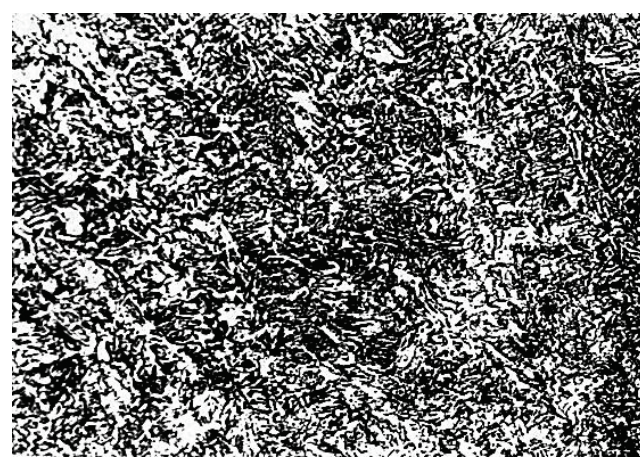

a)

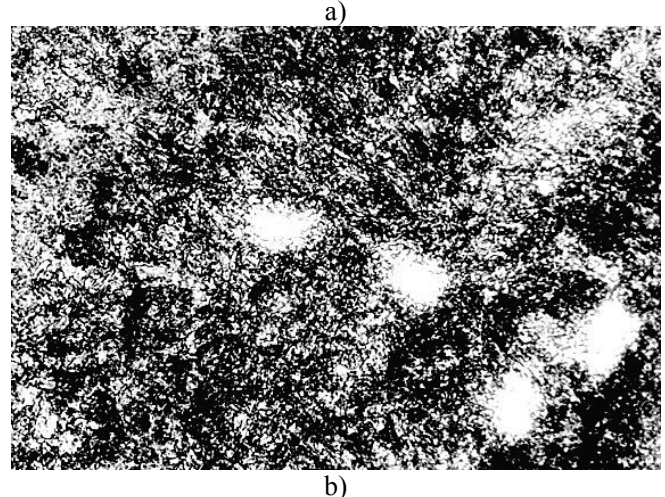

b)

Figure 5 Microstructure of the welding joint completed with AMIG procedure: a) WM (pearlite + ferrite + bainite) $(\times 250)$, b) HAZ (pearlite + ferrite + bainite $)(\times 250)$

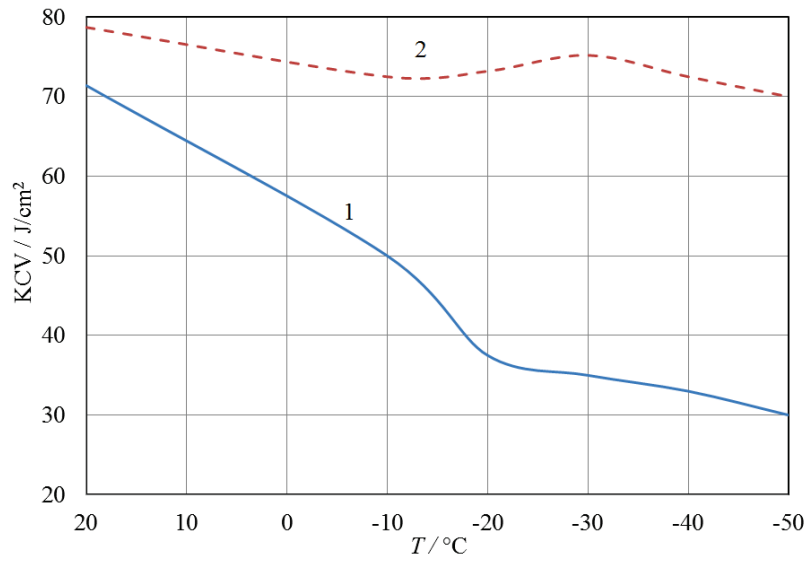

Figure 6 Impact toughness of the welding joint completed with AMIG procedure: 1 - BM (base metal), 2 - WM (weldmetal)

So, the examination results show that the use of activating fluxes is beneficial in order to reduce the intensity of driving energy and, at the same time, increase process productivity and improve welding joints quality. Maximum efficiency while using activating fluxes and non-consumable electrode (ATIG) is achieved with the steel thickness of $6 \div 8 \mathrm{~mm}$. Welding of the steel with its thickness of $8 \div 10 \mathrm{~mm}$, is more efficient with the use of consumable electrodes with activating fluxes (AMIG).

Apart from driving energy, energy efficiency of a welding process may be assessed through indicators, such as: thermal coefficient of arc penetration $\left(\eta_{\mathrm{t}}\right)$ and total heat coefficient of arc penetration $\left(\eta_{\mathrm{u}}\right)$. Thermal coefficient of arc penetration characterises the efficiency of the used material which is inserted into the welding joint in order to achieve metal root penetration. Total heat coefficient of arc penetration characterises the heat efficiency of electric arc penetration process.
These indicators are calculated in accordance with the methodology found in literature [7, 8], by using experimentally obtained data.

Tab. 6 shows the change of driving energy and coefficients $\eta_{\mathrm{t}}$ and $\eta_{\mathrm{u}}$ depending on the thickness of materials and welding procedure with non-consumable electrode shielded in argon gas. These data confirm that the use of activating fluxes increases $\eta_{\mathrm{t}}$ when compared to the conventional TIG welding procedure. However, with the increase of steel thickness, the difference between $\eta_{\mathrm{t}}$ for TIG and ATIG processes gradually decreases.

Table 6 Thermal $\left(\eta_{\mathrm{t}}\right)$ and total $\left(\eta_{\mathrm{u}}\right)$ electric arc penetration coefficient with non-consumable electrode arc welding

\begin{tabular}{|c|c|c|c|c|}
\hline $\begin{array}{c}\text { Material } \\
\text { thickness } \\
\delta / \mathrm{mm}\end{array}$ & $\begin{array}{c}\text { Welding } \\
\text { procedure }\end{array}$ & $\begin{array}{c}\text { Driving energy } \\
q_{i} / V_{w} / \mathrm{J} / \mathrm{cm}\end{array}$ & $\eta_{\mathrm{t}}$ & $\eta_{\mathrm{u}}$ \\
\hline \multirow{2}{*}{4} & $\mathrm{TIG}$ & 5825 & 0,12 & 0,070 \\
\cline { 2 - 5 } & $\mathrm{ATIG}$ & 3050 & 0,31 & 0,184 \\
\hline \multirow{2}{*}{5} & $\mathrm{TIG}$ & 6864 & 0,28 & 0,166 \\
\cline { 2 - 5 } & $\mathrm{ATIG}$ & 4627 & 0,35 & 0,212 \\
\hline \multirow{2}{*}{6} & $\mathrm{TIG}$ & 8669 & 0,39 & 0,234 \\
\cline { 2 - 5 } & $\mathrm{ATIG}$ & 5949 & 0,45 & 0,270 \\
\hline
\end{tabular}

While using ATIG procedure with $4 \mathrm{~mm}$ thick steel, the necessary driving energy is $47,64 \%$ less when compared to the conventional TIG procedure. With the increase of the thickness of steel, this difference decreases, so for $6 \mathrm{~mm}$ thick steel it is $31,38 \%$.

While utilising TIG welding of $4 \mathrm{~mm}$ thick steel, thermal coefficient of arc penetration $\left(\eta_{t}\right)$ is 2,58 times less than with ATIG welding. With the increase of steel thickness to $5 \mathrm{~mm}$, while it is still possible to use a single pass welding, the difference between $\eta_{\mathrm{t}}$ coefficients for TIG and ATIG procedure decreases to $25 \%$. With the thickness of $6 \mathrm{~mm}$, with a single pass welding, the difference between them is $15,38 \%$.

The same can be said for total heat coefficient of arc penetration $\left(\eta_{\mathrm{u}}\right)$ while utilising TIG and ATIG welding (Tab. 6).

In conclusion, we may say that the increase of the thickness of the metal which can be welded with a single pass, the intensity of the increase of thermal $\left(\eta_{\mathrm{t}}\right)$ and total $\left(\eta_{\mathrm{u}}\right)$ arc penetration coefficient for ATIG decreases, and the difference between these indicators for TIG and ATIG welding decreases.

The same can be said for AMIG procedure, only with thicker materials. Tab. 7 shows the change of driving energy and coefficients $\eta_{\mathrm{t}}$ and $\eta_{\mathrm{u}}$ depending on the arc penetration capability and welding procedure with consumable electrode (material is $10 \mathrm{~mm}$ in thickness).

Table 7 Thermal $\left(\eta_{\mathrm{t}}\right)$ and total $\left(\eta_{\mathrm{u}}\right)$ electric arc penetration coefficient with consumable electrode arc welding

\begin{tabular}{|c|c|c|c|c|c|}
\hline $\begin{array}{c}\text { Material } \\
\text { thickness } \\
\delta / \mathrm{mm}\end{array}$ & $\begin{array}{c}\text { Welding } \\
\text { procedure }\end{array}$ & $\begin{array}{c}\text { Penetration } \\
\text { arc }\end{array}$ & $\begin{array}{c}\text { Driving } \\
\text { energy } \\
q_{\mathrm{i}} / V_{\mathrm{w}} / \mathrm{J} / \mathrm{cm}\end{array}$ & $\eta_{\mathrm{t}}$ & $\eta_{\mathrm{u}}$ \\
\hline \multirow{3}{*}{10} & $\mathrm{MIG}$ & 1 & 24964 & 0,59 & 0,44 \\
\cline { 3 - 6 } & \multirow{3}{*}{$\mathrm{AMIG}$} & 1,8 & 9189 & 0,71 & 0,53 \\
\cline { 3 - 7 } & & $2,0 \div 2,5$ & 8103 & 0,87 & 0,52 \\
\cline { 3 - 7 } & & $3 \div 4$ & 4400 & 0,95 & 0,71 \\
\hline
\end{tabular}

While welding $10 \mathrm{~mm}$ thick steel, with the increase of arc penetration capability by $80 \%$ (AMIG procedure), the necessary driving energy is 2,72 times less than with the 
conventional MIG procedure. With the increase of arc penetration capability, the difference between the necessary driving energy for AMIG in relation to MIG procedure significantly increases. For the arc penetration capability (AMIG procedure) which is 4 times higher than with MIG procedure, the necessary driving energy is 5,67 times less.

With the conventional MIG procedure which is involved in a single pass welding of $10 \mathrm{~mm}$ thick steel, thermal coefficient $\left(\eta_{\mathrm{t}}\right)$ of arc penetration is 0,59 . Activating fluxes increase arc penetration capability by 1,8 times, which provides for $\eta_{\mathrm{t}}$ coefficient increase by $20,3 \%$. The increase of arc penetration capability by $2 \div 2,5$ times, increases $\eta_{\mathrm{t}}$ coefficient by $42,4 \%$ when compared with welding without the use of activating fluxes. With fourfold increase of arc penetration capability, thermal coefficient of electric arc penetration is higher than analogous indicators with a conventional welding procedure by $61 \%$.

Same change is valid for total $\left(\eta_{\mathrm{u}}\right)$ coefficient of arc penetration, which increases with the increase of arc penetration capability (Tab. 7)

These changes are valid for ATIG welding procedure as well.

\section{Conclusion}

Activating fluxes utilised with non-consumable (ATIG procedure) and consumable (AMIG procedure) electrode, thanks to the increased arc penetration capability, increase the productivity of welding and welding joints and at the same time decrease the consumption of energy during welding.

ATIG welding maintains higher efficiency with a single pass welding of 6 to $8 \mathrm{~mm}$ thick steel and with greater thickness (from 8 to $10 \mathrm{~mm}$ ) AMIG procedure is more efficient.

Increase of arc root penetration depth, which is achieved thanks to the application of activating fluxes, is followed by the increase of thermal $\left(\eta_{t}\right)$ and total $\left(\eta_{u}\right)$ coefficient of arc penetration. In such a manner, shielded arc welding efficiency is increased.

\section{References}

[1] Akulov, A. I.; Belchuk, G. A.; Demjancevich, V. P. Welding technology and equipment. Moscow, Mashinostroenie, 1977.

[2] Paton, B. E. Electric arc welding technology. Moscow, Mashinostroenie, 1974.

[3] Niagaj, J.; Savyćkyj, M. M.; Savyćkyj, O. M. The influence of activation on technological and ecological properties of welding arc under argon shield during welding of low- and high alloy steels. // Biuletynie Instytutu Spawalnictwa. 1(2008), pp. 46-50.

[4] Shorshov, M. H; Belov, V. V. Phase transformation and change of steel properties while welding. Moscow, Nauka, 1972.

[5] Savytsky, O. M.; Vasiliev, V. G.; Savytsky, M. M.; Vashchenko, V. N. Influence of the heating on structure formation of welding joints on hardening steels. // The Paton Welding Journal. 1(2005), pp. 15-17.

[6] Sterenbogen, Ju. A.; Petrov, P. F. Influence of the temperature range of crystallisation onto the affinity of steel to form crystal fractures while being welded. // Avtomaticheskaya Svarka. 7(1979), pp. 10-13.

[7] Begrianski, K. V.; Dobrotina Z. A.; Hrenov, K. K. Welding process theory. Kiev, The Higher School, 1976.

[8] Rikalin, N. N; Pugin, A. I. Welding thermal processes. Moscow, Profizdat Publishing Company, 1959.

[9] Frolov, V. V. Welding process theory. Moscow, The Higher School, 1988.

[10] Savytsky, M. M.; Leskov, G. I. Mechanism of impact of electro-negative elements onto the arc penetration with tungsten cathode. // Avtomaticheskaya Svarka. 9(1980), pp. $17-22$.

[11] Dudko, D. A; Savytsky, O. M.; Savytsky, M. M. Welding with shielded electrode while using activating flux. // Avtomaticheskaya Svarka. 10(1996), pp. 54-55.

[12] Savytsky, O. M.; Bajic, D.; Savytsky, M. M.; Vashchenko, V. N.; Lupan, A. F.; Skrabaliuk, Ju. M. Orbital welding technology of pipeline application of activating flux. // Welding \& Welded Structures. 3(2010), pp. 83-90.

\section{Authors' addresses}

Oleksandr M. Savytsky, Candidate of Technical Sciences

E. O. Paton Electric Welding Institute, Ukraine Bozhenko str. 11, $3680 \mathrm{Kiev,} \mathrm{Ukraina}$

E-mail:sam@paton.kiev.ua

Mychailo M. Savytsky, Ph.D.

E. O. Paton Electric Welding Institute, Ukraine Bozhenko str. 11, $3680 \mathrm{Kiev,} \mathrm{Ukraina}$

E-mail: savitsky@paton.kiev.ua

Dr. sc. Darko Bajić, Associate Professor

(Corresponding author)

University of Montenegro

Faculty of Mechanical Engineering

Džordža Vašingtona bb

81000 Podgorica, Montenegro

E-mail: darko@ac.me 